\title{
Flood events in Mediterranean ephemeral streams (ramblas) in Valencia region, Spain
}

\author{
Ana M. Camarasa Belmonte ${ }^{\mathrm{a}, *}$, Francesca Segura Beltrán ${ }^{\mathrm{b}, 1}$ \\ a Departamento de Geografía, Universidad de Alcalá, C/Colegios 2, 28801 Alcalá de Henares, \\ Madrid, Spain \\ ${ }^{\mathrm{b}}$ Departament de Geografia, Universitat de Valencia, Avda. Blasco Ibañez, 28, 46010 Valencia, Spain
}

Received 5 January 2000; received in revised form 15 February 2001; accepted 20 March 2001

\begin{abstract}
This article deals with flood events in Mediterranean ephemeral streams typical of the Valencia region. The combination of the basin physical characteristics (steep slopes, sparse vegetation, thin soils and permeable rock) and intense, heavy and irregularly distributed rain, generates flash floods. Runoff generation is sudden, giving rise to flash floods with sharp, narrow hydrographs with short time lags. The high amount of runoff is, nevertheless, only a small fraction of the total rainfall, since the characteristics of the river basins are such that infiltration of large amounts of water occurs. Using daily hydrological data from the Rambla de la Viuda basin and 5-min data from both the Barranc del Carraixet and the Rambla de Poyo basins, the rainfall-runoff processes have been analysed during flood events in these ephemeral streams. (C) 2001 Elsevier Science B.V. All rights reserved.
\end{abstract}

Keywords: Ephemeral streams; Hydrograph analysis; Runoff events; Rainfall-runoff relations; Spatial variability; Transmission losses

\section{Introduction}

The Mediterranean region is a bioclimatic, morphogenetic and hydrologic transition between the temperate, humid northern latitudes and the dry latitudes to the south. Despite the diversity of environments included in the term "Mediterranean" (Mateu, 1988), it still denotes a particular combination of complex climatic, structural and geomorphological factors.

\footnotetext{
${ }^{*}$ Corresponding author. Fax: +34-91-8854439.

E-mail addresses: anamaria.camarasa@uah.es (A.M. Camarasa Belmonte), Francisca.Segura@uv.es (F. Segura Beltrán).

${ }^{1}$ Fax: +34-96-3864249.
} 
In this geographic context, ephemeral streams are common fluvial systems. Rainfall and runoff processes in such streams have been studied in arid, semiarid and Mediterranean zones (Osborn and Lane, 1969; Karst, 1960; Rodier, 1981; De Vera, 1984; Schick, 1988; Sorriso-Valvo et al., 1995; Reid and Frostick, 1997; Martínez-Mena et al., 1998; Meirovich et al., 1998; Shentsis et al., 1999; Lange et al., 1999; etc.).

In the region of Valencia, rambla or barranc refers to ephemeral gravel-bed streams, hydrologically dependent on rainfall. Geomorphologically, these basins are small (several hundred square kilometres), with steep slopes, wide valleys and a braided channel morphology. These systems, which are usually dry for most of the year, become particularly active during flood events.

In Spain, despite the importance of these floods, the hydrological analysis of ephemeral streams has been difficult. On the one hand, perennial basins have been studied far more due to their greater economic importance. On the other hand, the lack of discharge and precipitation gauges and the frequency of data collection, usually daily, mask the hydrological processes that can occur in a matter of hours. However, since 1988, a new hydrological network, the Automatic Hydrological Information Systems (SAIH) network, has been in operation, providing detailed information in real time. This network has been developed by the Hydraulic Divisions, and measures rainfall and river discharge every 5 min.

This paper analyses the hydrological processes of flood events in three Mediterranean ephemeral streams, taking into account the peculiarities of the rainfall and morphology patterns of the study area. Daily and other detailed information (every $5 \mathrm{~min}$ ) has been used to study rainfall-runoff relationships, spatial and temporal rainfall variability and flash flood characteristics.

\section{Description of the study area and hydrological data}

In the study area (Fig. 1), three drainage basins, Rambla de la Viuda, Rambla de Poyo and Barranc del Carraixet, have been selected as representative cases for study. They are located in the eastern sector of the Iberian mountain chain (NNW-SSE). The relief results from folding and fracturing during the Alpine Orogeny, and forms stepped horst and grabens running parallel to the coast. The areas of these drainage basins range from $1289 \mathrm{~km}^{2}$ (Rambla de la Viuda) to $187 \mathrm{~km}^{2}$ (Rambla de Poyo) and $128 \mathrm{~km}^{2}$ (Barranc del Carraixet). Due to the proximity of the crests of the hills to the sea, the slopes are steep.

The dominant rock type in the headwaters is basically limestone in the Rambla de la Viuda, limestone and marls in the Rambla de Poyo, and limestone and sandstone in the Barranc del Carraixet. The limestone substrate, with a high degree of fracturing, fissuring and karstification, favours infiltration and percolation through karstic perched aquifers, unconnected to channels. The lower parts of the basins are located on the coastal plains and are formed by tertiary and quaternary alluvial deposits. Alluvial fans and glacis have been developed in the transition between headwaters and the coastal areas. 


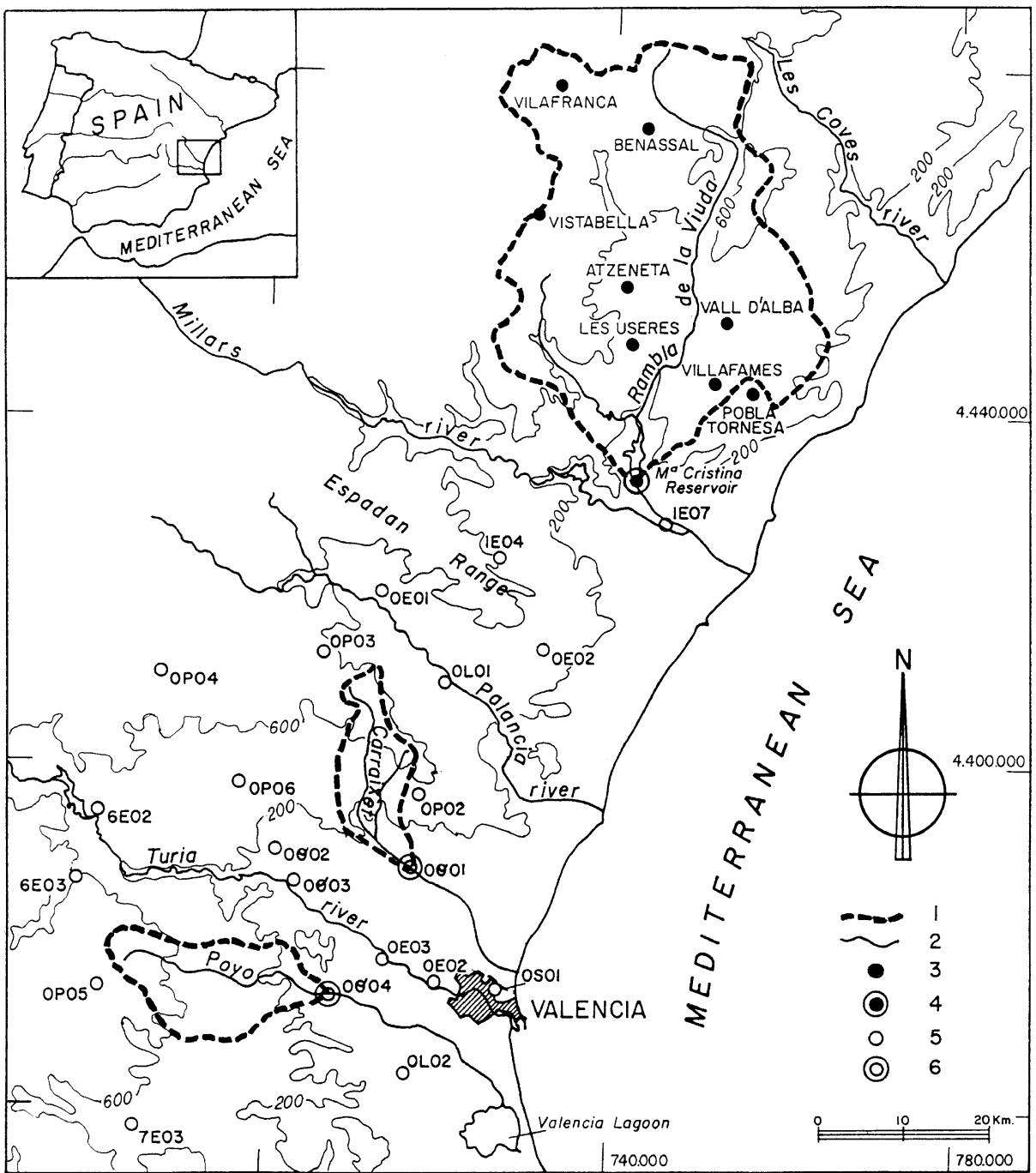

Fig. 1. Study area: (1) limit of the drainage basins; (2) fluvial streams; (3) daily rain gauges; (4) daily discharge gauges; (5) 5-min rain gauges-SAIH network; (6) 5-min discharge gauges-SAIH network.

The channels at the headwaters are deep and narrow, and encourage the processes of flood wave translation. In the lower basins, on the other hand, the width of transverse sections may be 100 times the depth. In this sector, gravel-bed channels flatten the hydrographs by rapid changes in channel geometry and high transmission losses (Segura, 1990).

The area has a typical Mediterranean climate with average annual rainfall ranging between 500 and $650 \mathrm{~mm}$. Rains are most frequent and intense in the autumn, generally produced by the following synoptic conditions: (1) the entry into the Mediterranean of 
polar air masses in the upper layers of the atmosphere due to a trough in the polar jet stream, (2) high atmospheric instability associated with strong thermal and humidity gradients, and (3) low pressure at ground level over the Magreb that generates humid east winds moving towards the Valencian coast. A secondary maximum is produced in the spring (frontal system), while the minimum is found in the summer (convective storms). The annual potential evapotranspiration oscillates between 750 and $800 \mathrm{~mm}$, although the real evapotranspiration is estimated at 450-550 mm (Sala Rosselló, 1994).

The hydrological analysis was based on both daily and 5-min data. The daily data for the Rambla de la Viuda, between 1959 and 1984, is the longest data series in this area. Nine rain gauges of the National Institute of Meteorology (INM) and one stream discharge gauge (Jucar Hydraulic Division) were used to study the rainfall-runoff relationships. At the same time, because daily data are not sufficiently accurate for characterising the hydrographs, 5-min data provided by the SAIH network have also been used. A total of 21 rain gauges and two stream discharge in the Rambla de Poyo and the Baranc del Carraixet have been used to study two specific flood events (Fig. 1). The lack of events and problems with data acquisition prevented us from studying more floods.

\section{Daily data: flood balances}

Ephemeral streams are dominated by extreme events of low frequency but high magnitude. The absence of base flow means that to discuss the hydrology of ephemeral streams is to discuss floods. Therefore, any analysis of flood balances of isolated events contributes to a better understanding of the processes involved in the genesis of runoff. Traditionally, such studies have been based on daily data. Although the precision of such data is insufficient for a detailed analysis of the development of the flood, they are very useful for studying the rainfall-runoff relation. In the following section, we discuss the results obtained with this type of data in the Rambla de la Viuda.

\subsection{Rainfall and runoff}

Between 1959 and 1984, in the Rambla de la Viuda, an average of about three events per year have been recorded. On average, there are 31 days per year ( $8 \%$ of the days) for which some runoff is registered, and the average length of an event is 8.2 days (Segura, 1990).

A review of the seasonal characteristics of the floods shows that the majority of the events occur during the transitional seasons, with $38 \%$ in autumn and $28 \%$ in spring. In winter, only $19 \%$ of the events occurred, and in summer, some 15\% (Segura, 1990) occurred. This seasonality, which is clearly dependent on the climate, is common in other very different areas of the Mediterranean, such as the Negev Desert (Greenbaum et al., 1998).

The volume of rain falling over the basin during each of these events was also very high. The analysis of rain gauge series from 35 floods (1959-1984) in the Rambla de la Viuda $\left(1289 \mathrm{~km}^{2}\right)$ showed that the rainfall volume was over $300 \times 10^{6} \mathrm{~m}^{3}$ in $11.5 \%$ of 
the events. The majority of events $(77 \%)$ showed values of between $100 \times 10^{6}$ and $300 \times 10^{6} \mathrm{~m}^{3}$, and only $11.5 \%$ of the events had less than $100 \times 10^{6} \mathrm{~m}^{3}$. With respect to the discharge volume, in $66 \%$ of the events it was less than $10 \times 10^{6} \mathrm{~m}^{3}$. In only $3 \%$ of the events did it pass $60 \times 10^{6} \mathrm{~m}^{3}$, while the other $31 \%$ of events had outputs between $10 \times 10^{6}$ and $60 \times 10^{6} \mathrm{~m}^{3}$. Also, a good correlation exists between the rainfall and runoff in the Rambla de la Viuda (Segura and Camarasa, 1996).

\subsection{Hydrological losses}

Despite the large amounts of discharge during floods, our data show that they corresponded to only a small part of the total rainfall. For example, in October 1962 when one of the biggest floods in this rambla occurred, the rainfall totalled $519.43 \times 10^{6}$ $\mathrm{m}^{3}$, while the discharge was only $85.98 \times 10^{6} \mathrm{~m}^{3}$ (Table 1 ).

These losses must be due to infiltration, evapotranspiration or transmission losses, but not necessarily with equal importance. Indeed, in Mediterranean ephemeral streams, water remains in the channel for too short a time for evaporation to be an important factor (Graf, 1988). It must therefore be infiltration and transmission losses that reduce or smooth the flood peak and the total discharge (Burkham, 1970). Transmission losses are important, especially downstream, where losses increase in proportion to the increase in channel width and the texture of the sediments (Jordan, 1977; Wallace and Lane, 1978; Thornes, 1976), as has been shown by the disappearance of runoff in the channels during these events. Keppel and Renard (1962) showed for streams in Arizona the importance of the peak and the previous humidity when estimating transmission losses. For a $6.4-\mathrm{km}$ stretch, these authors found that $35 \%$ of the runoff disappeared, while Hughes and Sami (1992), in a semiarid basin in South Africa found values that varied between $75 \%$ and $22 \%$ of the runoff. These studies corroborate the visual observations made for Valencian ephemeral streams, where the discharge is frequently seen to diminish along the length of the channel (Segura, 1990).

Water balances are usually calculated on the basis of annual totals, but this is not a very revealing procedure for ephemeral streams since flows are limited to floods, which can account for over $80 \%$ of the annual total in a single event (Segura and Camarasa, 1996). For this reason, it is advisable to establish balances that refer just to the periods of individual flood events. However, since it is difficult to directly measure the different loss processes, indirect techniques-runoff deficits, runoff coefficients and runoff thresholds-have to be used.

Table 1

The most important floods of the Rambla de la Viuda basin

\begin{tabular}{lllll}
\hline Event & $\begin{array}{l}\text { Rainfall } \\
\left(\times 10^{6} \mathrm{~m}^{3}\right)\end{array}$ & $\begin{array}{l}\text { Discharge } \\
\left(\times 10^{6} \mathrm{~m}^{3}\right)\end{array}$ & $\begin{array}{l}\text { Runoff deficit } \\
\left(\times 10^{6} \mathrm{~m}^{3}\right)\end{array}$ & $\begin{array}{l}\text { Runoff } \\
\text { coefficient }(\%)\end{array}$ \\
\hline October 1962 & 519.43 & 85.98 & 433.35 & 16.56 \\
October 1969 & 448.54 & 56.71 & 391.83 & 12.64 \\
November 1983 & 310.32 & 14.04 & 296.29 & 4.52 \\
December 1964 & 300.05 & 18.34 & 281.71 & 6.11 \\
\hline
\end{tabular}




\subsubsection{Runoff deficits}

Deficits, or differences between precipitation and discharge, are very significant in these ephemeral systems. All the events analysed in the Rambla de la Viuda had deficits over $50 \times 10^{6} \mathrm{~m}^{3}$, and in $86 \%$ of the cases, passed $100 \times 10^{6} \mathrm{~m}^{3}$. In addition, Fig. 2 shows how the deficits increased with rainfall, demonstrating the potential infiltration capacity of calcareous basins and the high rainfall amounts needed to reach saturation.

\subsubsection{Runoff coefficients}

Another way of measuring flow losses is by estimating runoff coefficients (Table 1). In the Rambla de la Viuda, these were very variable, ranging between $0.7 \%$ and $16.66 \%$. Of the 35 events studied, 23 had runoff coefficients of less than $5 \%$, and values of over $10 \%$ were only obtained for four events, with a maximum of $17 \%$. These figures give an idea of the large quantities of water that can infiltrate in these basins. More specific estimates calculated for flash floods of the Barranc del Carraixet and the Rambla de Poyo confirm the proportions between 5\% and 9\% (Segura and Camarasa, 1996). These results are also consistent with those obtained by other authors in semiarid areas. Peugeot et al. (1997) in the Sahel, where annual rainfall is around $560 \mathrm{~mm}$, obtained coefficients for individual events that oscillated between $10 \%$ and $90 \%$, with fairly impermeable lithologies (clays and calcretes). In Libya, De Vera (1984) obtained coefficients that varied between $0.22 \%$ and $20.26 \%$ for calcareous lithology basins, with

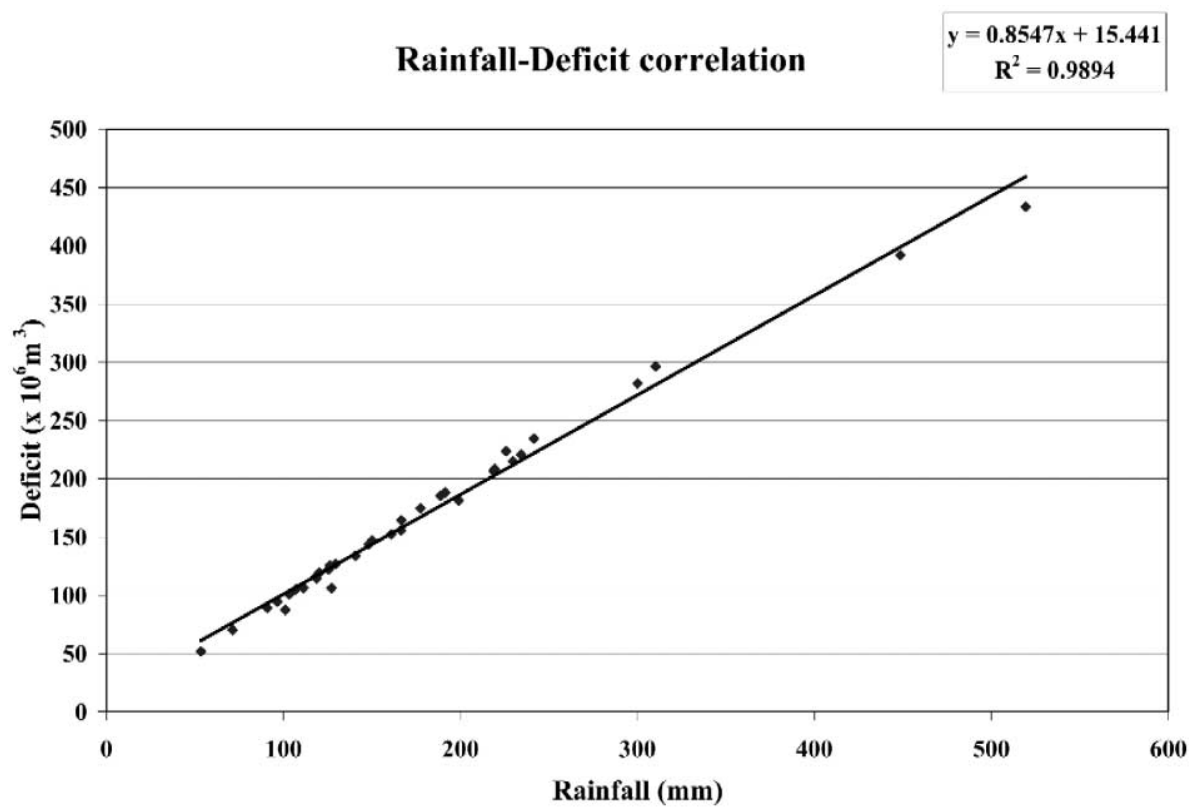

Fig. 2. Regression relation between rainfall and runoff deficit for individual storms in the Rambla de la Viuda basin, 1959-1984. 
Table 2

Comparison between runoff thresholds $(\mathrm{mm})$ estimated according to different methodologies

\begin{tabular}{lll}
\hline Gauge & $\begin{array}{l}\text { Osborn and } \\
\text { Lane (1969) }\end{array}$ & $\begin{array}{l}\text { US Soil Conservation } \\
\text { Service (1957) }\end{array}$ \\
\hline Autumn & 75 & 89 \\
Winter & 50 & 86 \\
Spring & 42 & 81 \\
Summer & 27 & 62 \\
\hline
\end{tabular}

karstification processes whose rainfall varied between the headwaters and the river mouth from 50 to $500 \mathrm{~mm}$.

In Valencian ramblas, the high variability of the coefficients within a single basin, in some cases, was related to the rainfall intensity and the moisture conditions before the event. For example, in the Rambla de Poyo during the 17 April 1991 event, the runoff coefficient was $12 \%$, higher than the $8 \%$ average, as a consequence of the smaller flood event 2 days earlier (Camarasa, 1995).

\subsubsection{Runoff thresholds}

Runoff thresholds provide a third indirect measure of water losses in the generation of discharge. This quantifies a rainfall limit $\left(P_{0}\right)$ below which runoff does not occur, that is, it indicates the amount of precipitation needed to generate surface flows in each event.

According to the method of Osborn and Lane (1969), the threshold value of the Rambla de la Viuda was $65 \mathrm{~mm}$ (Segura, 1990). However, in the River Monnegre (Alicante) in the south of the Valencia region, with a predominantly impermeable lithology, Segura et al. (1989) obtained thresholds between 35 and $40 \mathrm{~mm}$.

The contrast between the thresholds in lithologically distinct environments demonstrates the importance of the substrate in the infiltration process. Karstic limestones permit a high infiltration rate, while finer textures-silt, clay and calcretes-favour surface runoff, thus explaining the lower thresholds in the southern parts of Valencia region.

The runoff thresholds vary significantly for different events in the same basin, with a marked seasonal character: maxima in autumn and minima in summer (Table 2) (Segura and Camarasa, 1996). Although the average value for basins in the north of the Valencia region varied according to the calculation method used, ${ }^{2}$ the thresholds needed to generate runoff were higher in autumn $(75-89 \mathrm{~mm})$ and winter $(50-86 \mathrm{~mm})$ than in spring $(42-81 \mathrm{~mm})$ and summer $(27-62 \mathrm{~mm})$. These apparently contradictory data may be related to the type of rain and the behaviour of the soil. In summer, intense

\footnotetext{
${ }^{2}$ The method of Osborn and Lane (1969) is based on the general equation $Q=a P \pm b$; setting $Q=0$ and solving for $P$ ( $P=$ total precipitation and $Q=$ total runoff). The method of the US Soil Conservation Service (1957) is based on the Curve Number method and follows the equation $\sum R=\left(\sum P-P_{0}\right)^{2} / \sum P+4 P_{0}$ for $\sum P>P_{0}$, being $\sum R=0$ for $\sum P<P_{0} \quad\left(\sum R=\right.$ runoff caused by effective precipitation; $\sum P=$ precipitation accumulated from the beginning of the event; $P_{0}=$ runoff threshold).
} 
convective showers may alter the soil structure to quickly exceed the infiltration capacity and so generate Hortonian flows, while in autumn-winter, the rains are less intense but more persistent, and the system responds more gradually. In addition, hydrophobic soil behaviour is sometimes observed (Cerdá, 1995).

\section{Five-minute data: spatial and temporal variability of flood processes}

The importance of the effect of spatial and temporal variability of rainfall on runoff has been described by many authors at many scales (Osborn and Lane, 1969; Woolhiser and Goodrich, 1988; Nouh, 1990; Faurés et al., 1995; Goodrich et al., 1995). For small basins, it has a significant influence over peak discharge and total runoff (Osborn, 1984), which explains the difficulties experienced in trying to design models that accurately simulate the peak flows (Nouh, 1990). Over large basins, rainfall can be extremely patchy, affecting only a fraction of the drainage basin (Renard and Keppel, 1966; Reid et al., 1998). Within the area affected by the rain, the variations are related to the mobility of the convective cells (Yair and Lavee, 1985; Sharon, 1981). Furthermore, multiple-peak floods can result from multiple rainfall cells moving over the basin, or as a result of the unsynchronised contributions of tributaries to the main channel (Reid et al., 1998).

Daily data are clearly insufficient to study the spatial and temporal variability of the hydrological processes in these ephemeral streams (Pilgrim et al., 1988; Greenbaum et al., 1998). For this reason, 5-min data provided by the SAIH network have been used for the detailed analysis of the Carraixet and Poyo basins.

\subsection{Rainfall intensity: temporal variability}

In the basins studied, at a detailed scale within each event, there is enormous temporal and spatial rainfall variability. Powerful convective cells can yield large volumes of water for a few minutes at intensities of more than $100 \mathrm{~mm} / \mathrm{h}$ over limited areas, while only a few kilometres away, it may rain only at low intensity or not at all (Camarasa, 1994).

The internal structure of storms varies according to the temporal scale (Waymire and Gupta, 1981; Valdés et al., 1985). As the observation interval is reduced, intensity becomes more significant and emphasises the concentrated character of the precipitation. Fig. 3 compares the same hyetographs calculated (a) every $5 \mathrm{~min}$ and (b) every hour. In the first the maximum, intensity is over $100 \mathrm{~mm} / \mathrm{h}$, while in the second, it hardly reaches $45 \mathrm{~mm} / \mathrm{h}$.

In the SAIH network of the Jucar Hydraulic Division, it is usual to obtain 5-min maximum intensities over $120 \mathrm{~mm} / \mathrm{h}$ at some station at least once per year. For the bigger events, it is usual to find hyetographs with maximum intensity intervals of over $100 \mathrm{~mm} / \mathrm{h}$, although the average intensities are only 3 or $4 \mathrm{~mm} / \mathrm{h}$, giving variation coefficients over $300 \%$. Table 3 is an example, summarising the general characteristics of various hyetographs in the Valencia Region during the event of 8th and 9th September 1990. Note station 0L01, where $64.8 \mathrm{~mm}$ fell in less than $5 \mathrm{~h}$. The dispersion 
a

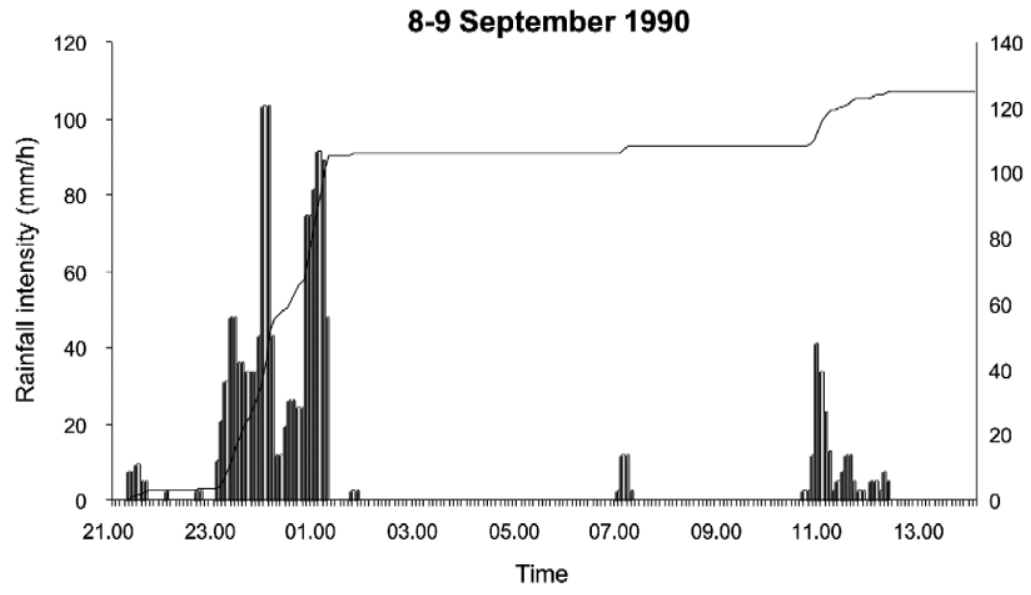

b

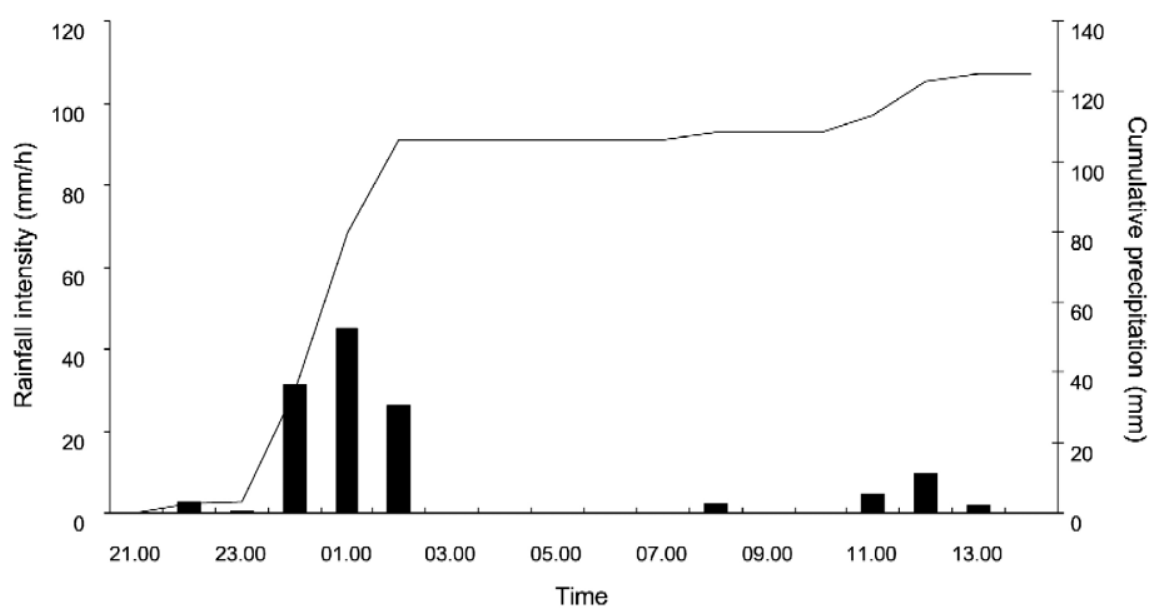

Fig. 3. Hyetograph of Carraixet (0O01) gauge, during the event from 8-9 September, 1990, registered at different time intervals: (a) every $5 \mathrm{~min}$, (b) every hour.

parameters of the rainfall intensities (standard deviation and variation coefficient) confirm that they were concentrated. The greatest contrasts appeared at $0 \mathrm{O} 01$, with a total of $125 \mathrm{~mm}$ and a difference between maximum $(103.2 \mathrm{~mm} / \mathrm{h})$ and average $(8.28$ $\mathrm{mm} / \mathrm{h}$ ) intensities of $94.9 \mathrm{~mm} / \mathrm{h}$. The standard deviation was 19.5 . Looking at the coefficient of variation, only one hyetograph had a value of less than $100 \%$. The rest were well above this figure, reaching $361 \%$ at 0004 . 
Table 3

Rainfall characteristics of the 8-9 September 1990 event

\begin{tabular}{llclccc}
\hline $\begin{array}{l}\text { Rain } \\
\text { gauge }\end{array}$ & $\begin{array}{l}\text { Duration } \\
(\mathrm{h})\end{array}$ & $\begin{array}{l}\text { Total } \\
\text { rainfall } \\
(\mathrm{mm})\end{array}$ & $\begin{array}{l}\text { Maximum } \\
\text { intensity } \\
(\mathrm{mm} / \mathrm{h})\end{array}$ & $\begin{array}{l}\text { Average } \\
\text { intensity } \\
(\mathrm{mm} / \mathrm{h})\end{array}$ & $\begin{array}{c}\text { Standard } \\
\text { deviation }\end{array}$ & $\begin{array}{l}\text { Variation } \\
\text { coefficient } \\
(\%)\end{array}$ \\
\hline 0E01 & 4.75 & 23.6 & 19.2 & 4.8 & 4.66 & 97 \\
0E02 & 14.66 & 51.7 & 69.6 & 3.5 & 10.5 & 300 \\
0E03 & 14.41 & 40.1 & 43.2 & 2.76 & 7.4 & 268 \\
0O01 & 15 & 125 & 103.2 & 8.28 & 19.5 & 235 \\
0O03 & 16.58 & 71.9 & 93.6 & 4.3 & 12.79 & 297 \\
0O04 & 15.5 & 27.7 & 48 & 1.77 & 6.39 & 361 \\
0P01 & 19.25 & 47.9 & 62.4 & 2.47 & 7.75 & 313 \\
0P02 & 15.5 & 152.7 & 91.2 & 11.04 & 25.04 & 226 \\
0P03 & 15.83 & 38.6 & 21.6 & 2.42 & 4.89 & 202 \\
0P04 & 4.66 & 28.4 & 48 & 5.97 & 8.89 & 149 \\
0P05 & 18 & 11.9 & 7.2 & 0.65 & 1.28 & 197 \\
0P06 & 16.58 & 34.8 & 36 & 2.08 & 5.6 & 269 \\
0L01 & 4.75 & 64.8 & 74.4 & 13.4 & 18.65 & 139 \\
0L02 & 14.25 & 18 & 24 & 1.23 & 3.85 & 313 \\
0S01 & 13.5 & 13.7 & 16.8 & 1 & 2.73 & 273 \\
6E02 & 15 & 38 & 45.6 & 2.51 & 6.7 & 267 \\
6E03 & 16.75 & 28.8 & 38.4 & 1.69 & 5.45 & 322 \\
0002 & - & 1.1 & 2.4 & - & - & - \\
\hline
\end{tabular}

\subsection{Rainfall intensity: spatial variability}

The spatial structure of rainfall shows a natural hierarchy with convective cells, small mesoscale areas (SMSA), large mesoscale areas (LMSA) and synoptic areas (Austin and Houze, 1972; Sharon, 1972; Gupta and Waymire, 1979). These scales may appear individually or in any combination (Camarasa, 1993). Fig. 4f — an hourly intensity map of a central sector of the Valencia region covering the 19:10-19:15 time interval of 11 November 1988-shows a generalised low intensity rainfall, corresponding to the large mesoscale, within which appear several convective cells that could form a small mesoscale area parallel to the coast. While in Fig. 5b (map corresponding to 23:05-23:10 of 8 September 1990), some convective cells are shown in the middle of a dry area.

These spatial structures, and particularly the convective cells, are greatly affected by the relief. On the one hand, the relief determines the preferred routes for incoming unstable air masses. Very often, the valleys open to the Mediterranean, with an upstream "cul-de-sac" shape, are used by the easterly winds to enter into the interior of the continent. Thus, convective cells are more probably produced in these valleys (Fig. 4c). On the other hand, the increase in elevation provokes a "mechanical trigger" forcing the unstable air masses upwards and favouring precipitation (Fig. 4d).

These maps suggest two distinct "rain cell behaviour patterns", one for the mountain and one for the coastal plain. The shapes of the hyetographs also reflect these two rain mechanisms. In the mountains, high volumes of precipitation fall with a continuous pattern shown as abundant "background noise", from which emerge some intense peaks. 

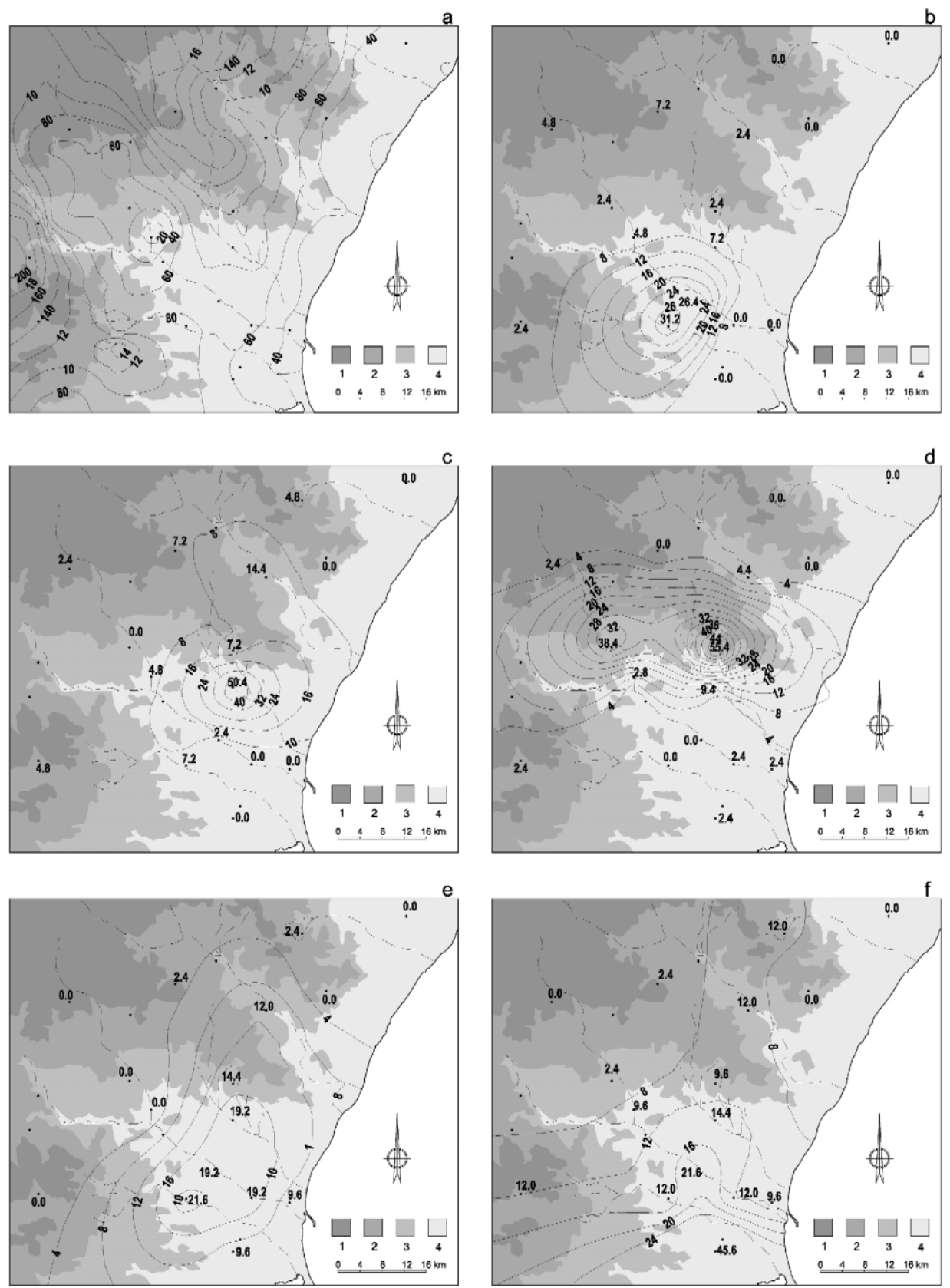

Fig. 4. Storm of 11-12 November 1988: (a) total rainfall (mm); (b) rainfall intensity $(\mathrm{mm} / \mathrm{h})$ at 10:40; (c) rainfall intensity $(\mathrm{mm} / \mathrm{h})$ at 11:00; (d) rainfall intensity $(\mathrm{mm} / \mathrm{h})$ at 18:05; (e) rainfall intensity $(\mathrm{mm} / \mathrm{h})$ at 18:50; (f) rainfall intensity $(\mathrm{mm} / \mathrm{h})$ at 19:10. 

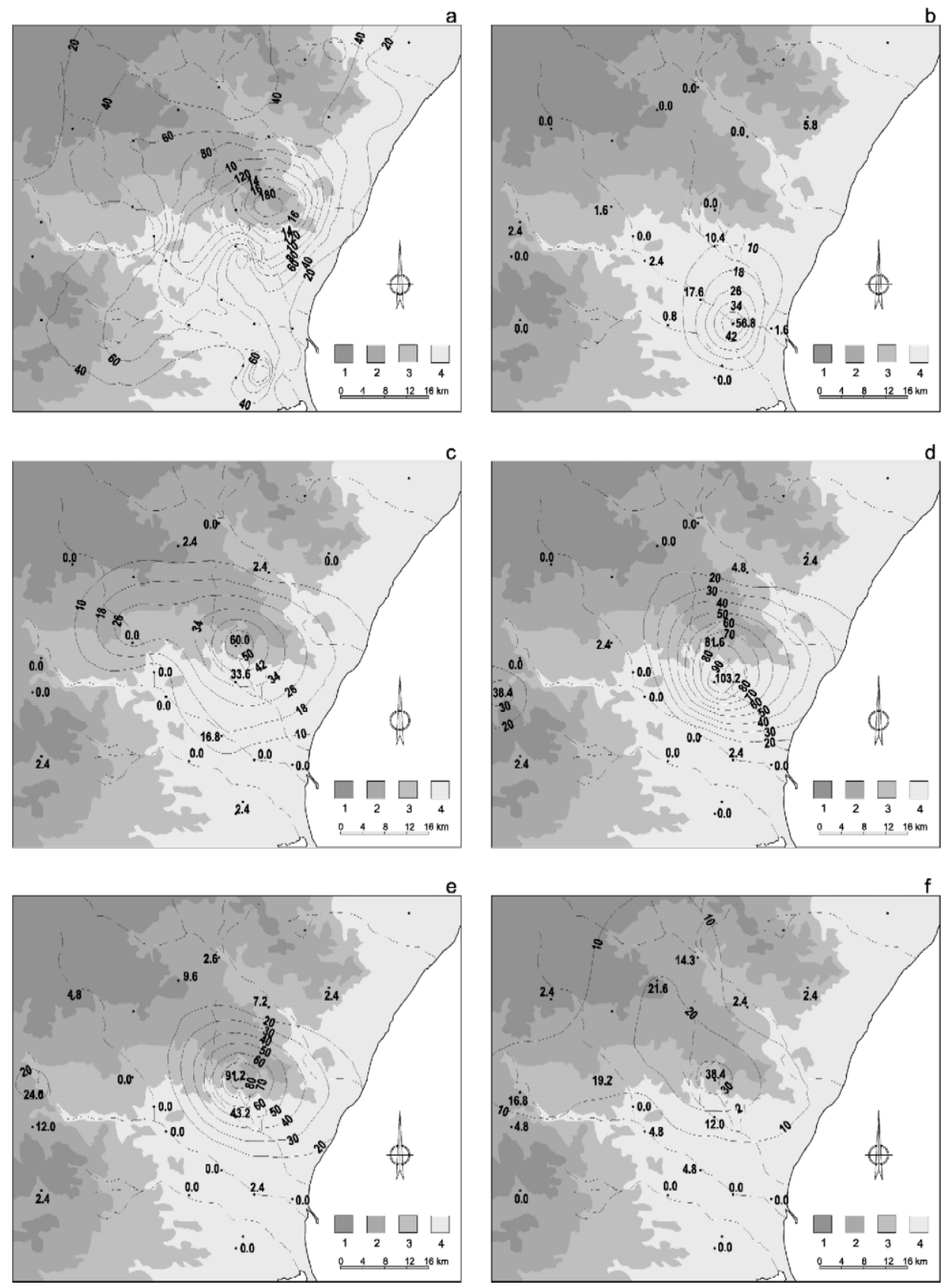

Fig. 5. Storm of 8-9 September 1990: (a) total rainfall (mm); (b) rainfall intensity (mm/h) at 23:05; (c) rainfall intensity $(\mathrm{mm} / \mathrm{h})$ at 23:40; (d) rainfall intensity $(\mathrm{mm} / \mathrm{h})$ at $24: 00 ;(\mathrm{e})$ rainfall intensity $(\mathrm{mm} / \mathrm{h})$ at $00: 10$; (f) rainfall intensity $(\mathrm{mm} / \mathrm{h})$ at $00: 20$. 
The cumulative hyetographs show irregular but continuous rises, separated by short stabilisation steps. In the littoral, the rain is more concentrated, with isolated high intensity peaks. The cumulative hyetographs are stepped with almost vertical rises interrupted by long horizontal sections.

The hyetographs of the stations $0 \mathrm{P} 03$ and 0004 , registered during the event of November 1988, provide an example. Station 0P03, located within the mountainous area, totalled $170.7 \mathrm{~mm}$ in $32 \mathrm{~h} 40 \mathrm{~min}$ (Fig. 6A). The rain was concentrated in the

A

\section{Cueva Santa (0P03) \\ 11-12 th November 1988}

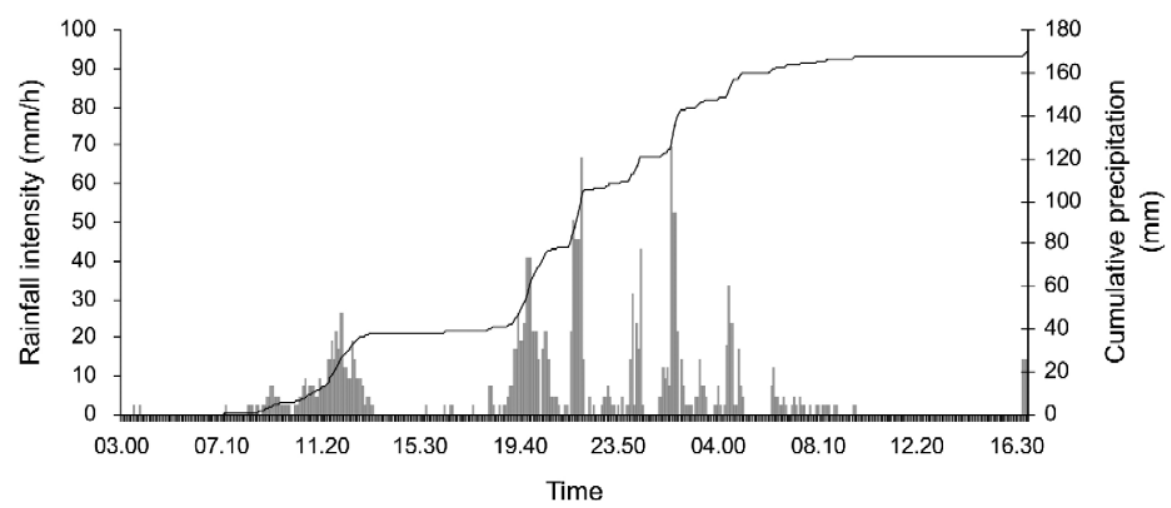

B

11-12th November 1988

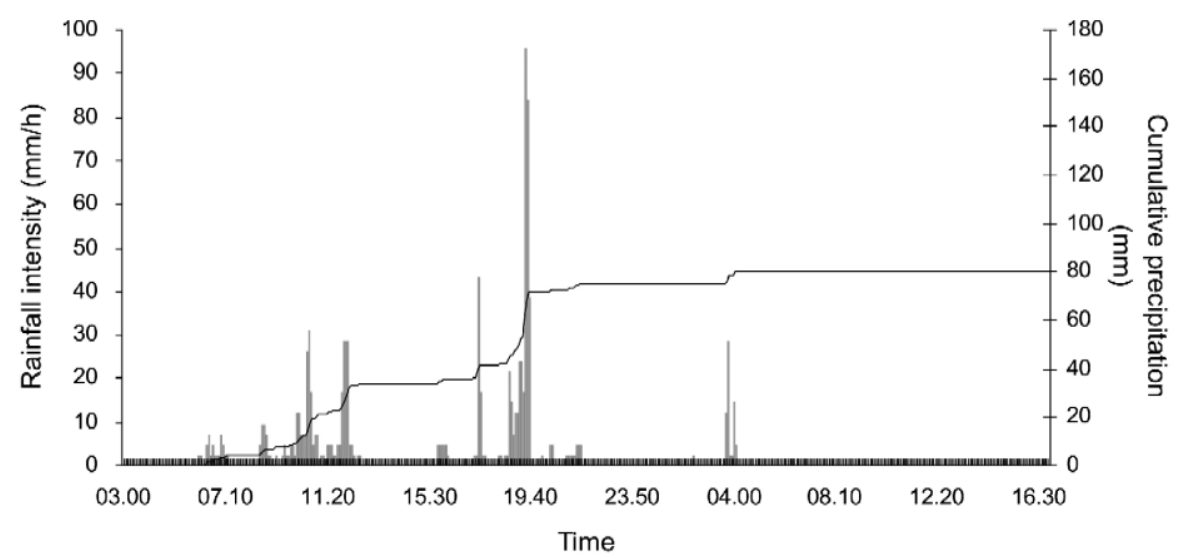

Fig. 6. Hyetographs registered during the event of 11-12 November 1988; (A) Cueva Santa (OP03) rain gauge; (B) Rambla de Poyo (0O04) rain gauge. 
central period which lasted $10 \mathrm{~h} 40 \mathrm{~min}$, and totalled $120.5 \mathrm{~mm}$ (70\% of the total), with a maximum intensity of $69.6 \mathrm{~mm} / \mathrm{h}$. It had two features: abundant and persistent background "noise" and five peaks, whose intensities ranged between 33.6 and 69.6 $\mathrm{mm} / \mathrm{h}$.

The hyetograph from the littoral station 0004 shows a total of $80.6 \mathrm{~mm}$ in $22 \mathrm{~h}$ (Fig. 6B), divided among four nuclei (Table 4). The third of these had the highest intensity $(96 \mathrm{~mm} / \mathrm{h})$, and accounted for $44.2 \%$ of the total for the event in slightly over $2 \mathrm{~h}$. The maximum intensities were above those in the previous example, but they lasted less, and there was hardly any low intensity "background".

This combination of two rainfall pattern has been corroborated elsewhere by detailed analysis of three rainfall events (Camarasa, 1993, 1995). As a representative example, Fig. 7 shows maximum intensities plotted against storm totals registered for various hyetographs from the event of 11-12 November 1988. The stations are grouped along two clearly defined lines. Regression line "a" corresponds to observation stations above $200 \mathrm{~m}$, while "b" groups the stations at lower altitudes. The highest amounts of rain are found in the mountains (Figs. 4a and 5a), but the greatest intensities on the coast.

To test whether this behaviour corresponded to two distinct populations, the $U$-test of Mann-Whitney was applied to the quotient of the two variables (cumulative precipitation and maximum intensity). The behaviour for the mountain and the littoral was found

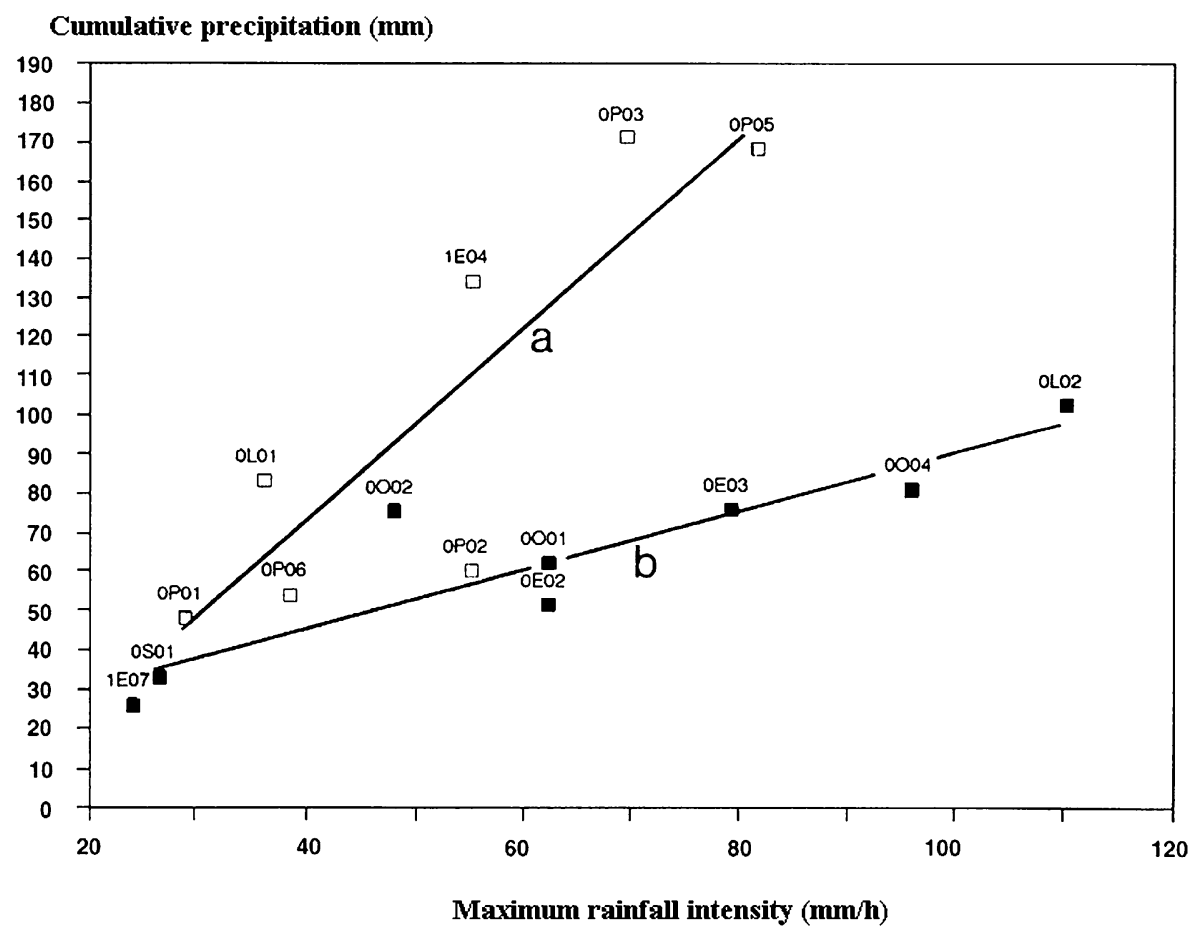

Fig. 7. Relation between total cumulative precipitation and maximum intensity rainfall registered during the November 1988 event: (a) rain gauges above 200 m; (b) rain gauges below $200 \mathrm{~m}$. 
to be statistically distinct with $95 \%$ significance. This can be explained by the differences in the type of trigger and the development of vertical instability. Relief affects the majority of the convective cells, which are forced to rise until they develop instability, whereas the cells that shed rain on the coastal plains already have sufficient instability to precipitate, without the need for an initial external mechanical trigger. This inherent instability leads to higher intensities, although the low frequency and short duration of convective cells produces lower accumulated amounts. Thus, two distinct rainfall patterns are observed for the mountain and the coast: the convective cells of greatest intensity, shortest duration and fastest movement affect the littoral, while the more persistent, intermediate intensity and slower moving cells precipitate over the mountains.

\subsection{The output hydrographs}

The analysis of the hydrographs of ephemeral streams is relatively simple since there is no baseflow. In all the cases studied, whether the flood lasted a few days or a few hours, the shape of the hydrograph was typical of a flash flood: very sharp, with a short time base and steeply rising limbs.

These characteristics were evident even when using daily average data. The record from the Rambla de la Viuda showed many single-peaked hydrographs, but also contains many examples of multi-peaked flood hydrographs. As an example, Fig. 8 shows the flood of the Rambla de la Viuda during 5-29 October 1969. The hydrograph reproduces the rainfall pattern, with two peaks, and with the maximum discharge-250 $\mathrm{m}^{3} / \mathrm{s}$ - reached in three days. The lag to peak-defined as the time difference between the centre of mass of rainfall and the peak runoff rate (Dunne and Leopold, 1978) — was 1 day. In total, the discharge lasted 25 days, and the rain 8 days.

\section{Time (days)}

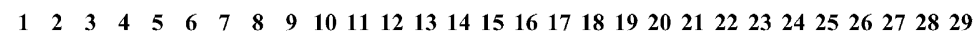

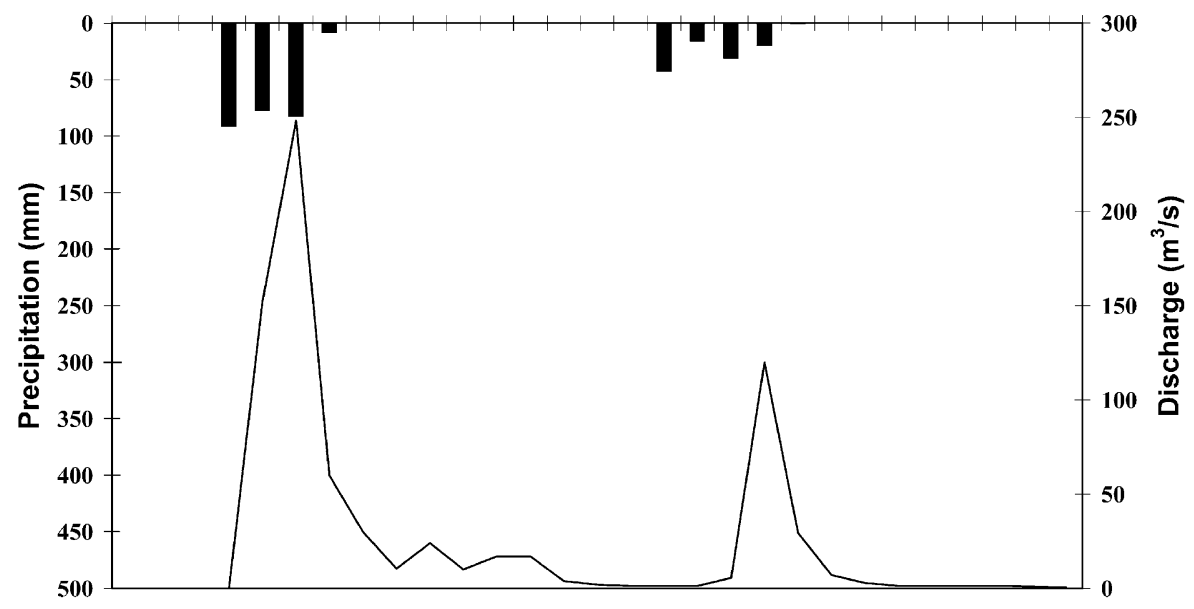

Fig. 8. Flood hydrograph registered daily in the Rambla de la Viuda basin (5-29 October 1969). 
With 5-min interval data, examples of single flood peaks, corresponding to the Poyo (11 and 12 November 1988) and the Carraixet (9 September 1990), are shown. In both hydrographs, the effective rainfall was estimated by subtracting from each interval the losses calculated using the water balance according to the US Soil Conservation Service (1957). The hydrograph of the Rambla de Poyo (Fig. 9) was generated by a cold low in the polar jet stream that provoked rain lasting several hours. The average total rainfall over the Poyo basin was $75 \mathrm{~mm}$, generating a runoff volume of $1.23 \times 10^{6} \mathrm{~m}^{3}$. Between 6:00 and 12:45 on the 11th (Fig. 6B), $33 \mathrm{~mm}$ fell (40\% of the total) as low intensity rain (Fig. 4b), with a maximum of $31 \mathrm{~mm} / \mathrm{h}$ (Table 4), moistening the soil. Between 17:25 and 19:40 (Fig. 6B), 44\% of the total fell (Table 4) with a maximum intensity of 96 $\mathrm{mm} / \mathrm{h}$, in a short time. In fact, a part of the time the basin received no rainfall (Fig. $4 \mathrm{c}$ and d) or the intensities were very low (Fig. 4b). Towards 19:10 (Fig. 4f), the rainfall intensified leading to the flood.

The hydrograph of the Poyo basin (Fig. 9) has a single peak, which was apparently due to a flood wavefront, since in $15 \mathrm{~min}$, the measurement rose from 0 to the maximum discharge of $193 \mathrm{~m}^{3} / \mathrm{s}$. The total duration was short, just $3 \mathrm{~h} 30 \mathrm{~min}$, and the surface discharge corresponded to $8 \%$ of the rainfall over the basin. The lag to peak and

Time

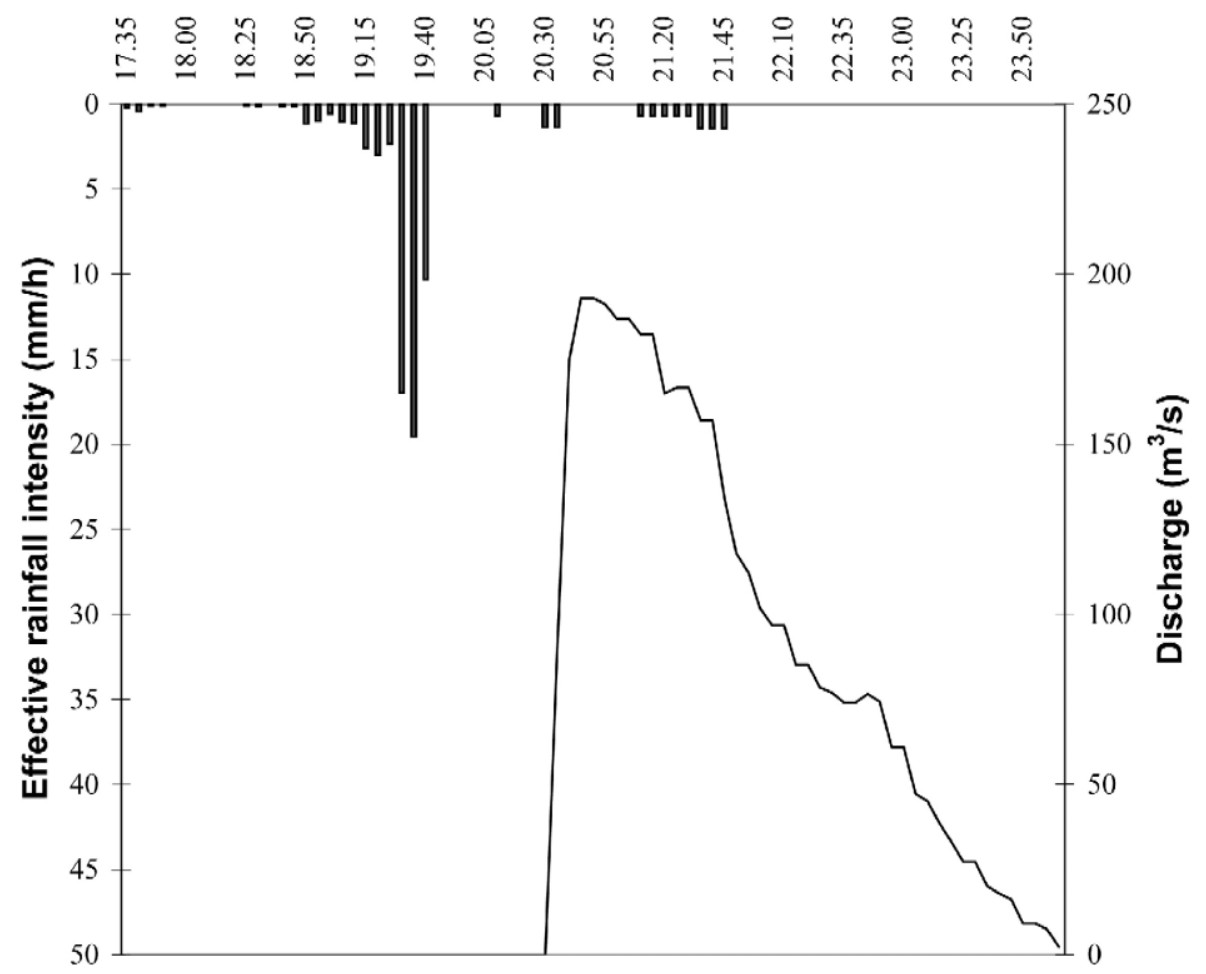

Fig. 9. Flood hydrograph registered every $5 \mathrm{~min}$ in the Rambla de Poyo basin (11-12 November 1988). 
Table 4

Hyetograph characteristics of the Rambla de Poyo (0O04) rain gauge (11-12 November, 1988)

The first three nuclei refer to 11 November; the fourth to 12 November. "Dry" intervals have no rain, or scattered low intensity rainfall only.

\begin{tabular}{lcccccccc}
\hline $\begin{array}{l}\text { Rainfall } \\
\text { nucleus }\end{array}$ & Real time & $\begin{array}{l}\text { Duration } \\
(\mathrm{h}, \mathrm{min})\end{array}$ & $\begin{array}{l}\text { Proportion } \\
\text { of time in } \\
\text { duration of } \\
\text { event }(\%)\end{array}$ & $\begin{array}{l}\text { Total } \\
\text { rainfall } \\
(\mathrm{mm})\end{array}$ & $\begin{array}{l}\text { Proportion } \\
\text { of total } \\
\text { rainfall } \\
(\%)\end{array}$ & $\begin{array}{l}\text { Maximum } \\
\text { intensity } \\
(\mathrm{mm} / \mathrm{h})\end{array}$ & $\begin{array}{l}\text { Average } \\
\text { intensity } \\
(\mathrm{mm} / \mathrm{h})\end{array}$ & $\begin{array}{l}\text { Standard } \\
\text { deviation }\end{array}$ \\
\hline 1 & $06: 05-07: 15$ & 1,10 & 5 & 3.8 & 4.7 & 7.2 & 3.04 & 2.08 \\
2 & $08: 35-12: 45$ & 4,10 & 18.2 & 29.2 & 36.3 & 31.2 & 6.87 & 8.15 \\
3 & $17: 25-19: 40$ & 2,15 & 9.9 & 35.4 & 44.2 & 96 & 15.17 & 23.7 \\
4 & $03: 45-04: 10$ & 0,25 & 1.8 & 4.4 & 5.5 & 18.8 & 8.8 & 9.26 \\
"Dry" & & 14,05 & 65.1 & 7.6 & 9.3 & - & - & - \\
$\begin{array}{l}\text { intervals } \\
\text { Total }\end{array}$ & & & & & & & & \\
\hline
\end{tabular}

concentration time-defined as the time that passes between the end of the effective rainfall and the end of the hydrograph (Viessman et al., 1989) — were also very short: 1 h $50 \mathrm{~min}$ and $2 \mathrm{~h} 20 \mathrm{~min}$, respectively. The shape of the hydrograph, with a sharp rise limb, is typical of the flood curve for flashy streams, with a morphology similar to those found in arid and semiarid environments (Schick and Sharon, 1974; Schick, 1988).

The hydrograph of 9 September 1990 in the Carraixet is less flashy (Fig. 10). It too was provoked by a cold low in the polar jet stream. The greatest precipitation occurred on the 8th over the headwaters of the basin (Fig. 5a), due to the orographic barrier effect of the mountains against the prevailing SE winds.

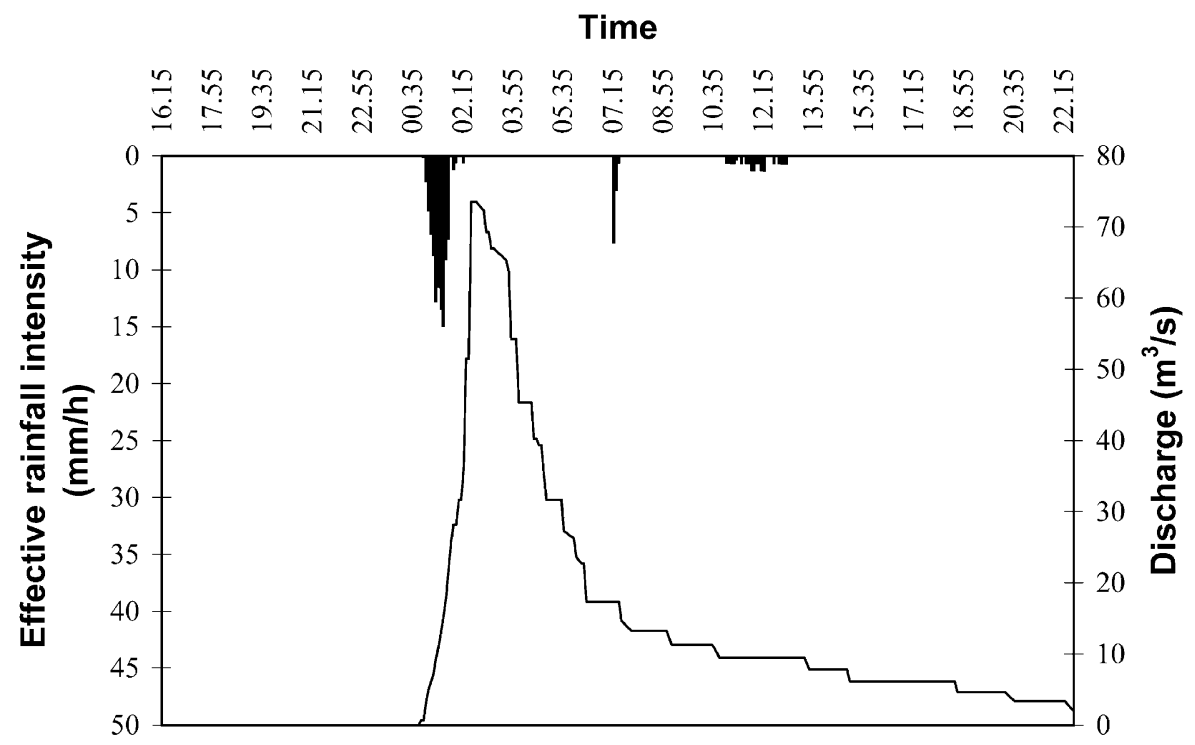

Fig. 10. Flood hydrograph registered every $5 \mathrm{~min}$ in the Barranc del Carraixet basin (9 September 1990). 
These rains formed an SMSA anchored over the basin. Within this, a small powerful cell is noteworthy, with great intensity-103 $\mathrm{mm} / \mathrm{h}$-centred some $8 \mathrm{~km}$ upstream from the gauge (Fig. 5). The average rainfall over the basin was some $153 \mathrm{~mm}$, generating a runoff volume of $1.27 \times 10^{6} \mathrm{~m}^{3}$. The rainfall was concentrated between 23:00 on the 8th and 01:50 on the 9th (Fig. 3a), with a maximum intensity of 103 $\mathrm{mm} / \mathrm{h}$. Around 23:05, an SMSA began to develop in the lower part of the basin (Fig. $5 \mathrm{~b}$ ), which then moved towards the north, reaching the upper part of the catchment at 23:40 (Fig. 5c), with an intensity of $60 \mathrm{~mm} / \mathrm{h}$. The activity of the principal cell was continuous during approximately $2 \mathrm{~h}$. The maximum was reached at 24:00 (Fig. 5d). Later, the intensity dropped progressively (Fig. 5e,f) before reactivating again around 10:55 with a maximum intensity of $40 \mathrm{~mm} / \mathrm{h}$ (Fig. 3).

The greater permeability of this basin-only $5 \%$ of the precipitation was converted into runoff-led to a more delayed response. The hydrograph base lasted $21 \mathrm{~h} 40 \mathrm{~min}$. The rising limb was still steep - the maximum discharge of $74 \mathrm{~m}^{3} / \mathrm{s}$ was reached in $1 \mathrm{~h}$ $40 \mathrm{~min}$ - but the recession limb was much longer, lasting $19 \mathrm{~h} 45 \mathrm{~min}$, as a consequence of the delayed subsurface flow contributions coming from the transitional sedimentary forms, fans and piedmonts, which predominate in the middle basin. The lag to peak-3 h 15 min-was still short. The concentration time of the basin was 8 h 40 min.

The use of the SAIH data, with great temporal detail, clarifies the role of the intensity in the generation of flood events in small basins, although the low density of stream gauges makes it difficult to analyse questions such as the contribution of the tributaries or the flow wave celerity (Reid et al., 1998). However, the simplicity of the hydrographs analysed suggests that in both cases, the determining factor in the flood events is the great intensity of the rainfall, although the total volumes were not especially high.

\section{Discussion and conclusions}

The hydrological behaviour of ephemeral streams in study area is dominated by extreme events. The ephemeral runoff, depending almost exclusively on rainfall, is clearly related to the characteristics of the drainage basin. Fractured, fissured and karstified calcareous substrates produce important aquifers at depth. These aquifers receive contributions from transmissions losses in the channels, but they do not contribute to create baseflow in beds.

Powerful convective cells precipitate large quantities of water in concentrated bursts. The rainfall volume and intensity is greatly affected by the relief: in east-facing regions, the rainfall is more intense over the coastal plains, but the greater volumes fall over the mountains. The intensity of the rainfall has been seen to be the factor that provokes flood events in small basins (Rambla de Poyo and Barranc del Carraixet). In the bigger basin (Rambla de la Viuda), it was not possible to define the importance of this factor, although the big floods always occur with large rainfall volumes. Nevertheless, other factors such as the synchronisation of the tributaries, the trajectory of the storms or the transmission losses ought to be critical for the generation of big flood events, as noted by Greenbaum et al. (1998). 
The large discharge losses are another feature of these flood events, since at most, $17 \%$ of the rainfall is converted to runoff. As a consequence of the rainfall pattern, flooding is typically in the form of flash floods. Depending on the characteristics of the storms and the synchronisation of the tributaries, the hydrographs can be simple or multipeak. In every case, the hydrographs are nevertheless very sharp, with high peaks and steep rises and short lag times. The response of the basins to intense rain occurs in just a few hours. The duration of the hydrographs is very variable depending on the characteristics of the rainfall and the dimensions of the basin.

Floods in Mediterranean ephemeral streams are especially rapid, violent and, therefore, dangerous. An understanding of the hydrological operation of these systems helps towards the correct planning of areas liable to flooding, as well as in the design of plans for prediction and protection that are sufficiently flexible to allow rapid and effective response. The real time detailed information networks (like SAIH) are of vital importance in facilitating the recognition and monitoring of the processes that generate floods with response times of a matter of hours, as is the case for Mediterranean ephemeral streams. However - as is noted by many authors (Pilgrim et al., 1988; Greenbaum et al., 1998) — the analysis of the spatial variability of the hydrological behaviour requires the existence of a denser network of rainfall and stream discharge gauges in a single basin, in order to evaluate better the mechanisms that generate floods.

\section{Acknowledgements}

This work has been financed by the Generalitat Valenciana, Project GV-D-RN 12-127-96. The hydrological data were kindly ceded by the Jucar Hydraulic Division (Confedracion Hidrográfica del Júcar). Critical reviews by A.P. Schick, other anonymous referees and S.W. Trimble are kindly acknowledged.

\section{References}

Austin, P.M., Houze Jr., R.A., 1972. Analysis of precipitation patterns. N. Engl. J. Appl. Meteorol. 11, 926-934.

Burkham, D.E., 1970. A method for relating infiltration rates to streamflow rates in perched streams. U.S. Geol. Surv. Prof. Pap. 700 D, 226-271.

Camarasa, A.M., 1993. La estructura interna de las tormentas mediterráneas. Cuad. Geogr. 54, $169-188$.

Camarasa, A.M., 1994. La intensitat de la precipitación. In: Pérez Cueva, A. (Ed.), Atlas Climàtic de la Comunitat Valenciana. C.O.P.U.T, València, pp. 100-101.

Camarasa, A.M., 1995. Génesis de crecidas en pequeñas cuencas semiáridas: Barranc del Carraixet y Rambla de Poyo. PhD Thesis. MOPT-Confederación Hidrográfica del Júcar, Valencia.

Cerdá, A., 1995. Factores y variaciones espacio-temporales de la infiltracion en los ecosistemas mediterráneos. Geoforma Ediciones, Logroño.

De Vera, M.R., 1984. Rainfall-runoff relationship of some catchments with karstic geomorphology under arid and semi-arid conditions. J. Hydrol. 68, 85-93.

Dunne, T., Leopold, L.B., 1978. Water in Environmental Planning. Freeman, San Francisco.

Faurés, J.M., Goodrich, D.C., Woolhiser, D.A., Sorooshian, S., 1995. Impact of small-scale spatial rainfall variability on runoff modelling. J. Hydrol. 173, 309-326. 
Goodrich, D.C., Faurés, J.M., Woolhiser, D.A., Lane, L.J., Sorooshian, S., 1995. Measurement and analysis of small-scale convective storm rainfall variability. J. Hydrol. 173, 283-308.

Graf, W.L., 1988. Fluvial Processes in Dryland Rivers. Springer, Berlin.

Greenbaum, N., Margalit, A., Schick, A., Sharon, D., Baker, V.R., 1998. A high magnitude storm and flood in a hyperarid catchment, Nahal Zin, Negev Desert, Israel. Hydrol. Processes 12, 1-23.

Gupta, V.K., Waymire, E.C., 1979. A stochastic kinematic study of subsynotic space-time rainfall. Water Resour. Res. 15 (3), 630-636.

Hughes, D.A., Sami, K., 1992. Transmission losses to alluvium and associated moisture dynamics in a semiarid ephemeral channel system in Southern Africa. Hidr. Processes 6, 45-53.

Jordan, P.R., 1977. Streamflow transmission losses in Western Kansas. J. Hydraul. Div., Proc. ASCE 103 (HY8), 905-919.

Karst, J., 1960. Les traits généraux du régime et les caractéristiques hydrologiques des oueds des provinces du nord du Maroc. Notes Maroc. 13, 35-43.

Keppel, R.V., Renard, K.G., 1962. Transmission losses in ephemeral streams. J. Hydraul. Div., Proc. ASCE 8 (HY3), 59-68.

Lange, J., Leibundgut, C., Greenbaum, N., Schick, A.P., 1999. A noncalibrated rainfall-runoff model for large, arid catchments. Water Resour. Res. 35 (7), 2161-2172.

Martínez-Mena, M., Albadalejo, J., Castillo, V.M., 1998. Factors influencing surface runoff generation in a Mediterranean semi-arid environment, Chicamo watershed, S.E. Spain. Hydrol. Processes 12, 741-754.

Mateu, J.F., 1988. Crecidas e inundaciones en el País Valenciano. Guía de la Naturaleza de la Comunidad Valenciana. Edicions Alfons el Magnànim, Diputacion Provincial de Valencia, pp. 595-636.

Meirovich, L., Ben-Zvi, A., Shentsis, I., Yanovich, E., 1998. Frequency and magnitude of runoff event in the arid Negev of Israel. J. Hydrol. 207, 204-219.

Nouh, M., 1990. Flood hydrograph estimation from arid catchment morphology. Hydrol. Processes 4, $103-120$.

Osborn, H.B., 1984. Storm-cell properties influencing runoff from small watersheds. Transportation Research Board, Transportation Research Record 922. National Research Council, National Academy of Sciences, Washington, DC, pp. 24-32.

Osborn, H.B., Lane, L.J., 1969. Precipitation-runoff relation for very small semiarid rangeland watersheds. Water Resour. Res. 5 (2), 419-425.

Peugeot, C., Esteves, M., Galle, S., Rajot, J.L., Vandervaere, J.P., 1997. Runoff generation processes: results and analysis of field data collected at the East Central Supersite of the HAPEX-Sahel experiment. J. Hydrol. 188-189, 179-202.

Pilgrim, D.H., Chapman, T.G., Doran, D.G., 1988. Problems of rainfall-runoff modelling in arid and semiarid regions. Hydrol. Sci. J. 33, 379-400.

Reid, I., Frostick, L.E., 1997. Channel form, flows and sediments in deserts. In: Thomas, D.S.G. (Ed.), Arid Zone Geomorphology. 2nd edn. Wiley, Chichester, pp. 205-229.

Reid, I., Laronne, B., Powell, D.M., 1998. Flash-flood and bedload dynamics of desert gravel-bed streams. Hydrol. Processes 12, 543-557.

Renard, K.G., Keppel, R.V., 1966. Hydrographs of ephemeral streams in the Southwest. J. Hydraul. Div., Proc. ASCE 92 (HY2), 33-52.

Rodier, J.A., 1981. Caracteres particuliers des regimes hydrologiques des zones arides. Eaux et Climates, Melanges Geographiques offerts en hommage à Charles-Pierre Peguy. University Joseph Fourier, Grenoble, pp. 473-486.

Sala Rosselló, I., 1994. L'evapo-transpiració. In: Pérez Cueva, A. (Ed.), Atlas Climàtic de la Comunitat Valenciana. C.O.P.U.T, València, pp. 111-113.

Schick, A.P., 1988. Hydrologic aspects of floods in extreme arid environments. In: Baker, R., Kochel, R.C., Patton, P.C. (Eds.), Flood Geomorphology. Wiley, New York, pp. 189-203.

Schick, A.P., Sharon, D., 1974. Geomorphology and Climatology of Arid Watersheds, Tech. Rep. Department of Geography, Hebrew University, Jerusalem.

Segura, F.S., 1990. Las ramblas valencianas, PhD Thesis.Universitat de València, 229 pp.

Segura, F.S., Camarasa, A., 1996. Balances hídricos de crecidas en ramblas mediterráneas: pérdidas hídricas. In: Marzol, M.V., Dorta, P., Valladares, P. (Eds.), Clima y agua: la gestión de un recurso climático. La Laguna University, Tenerife, pp. 235-245. 
Segura, F.S., Pardo, J.E., Burguet, I., Sapiña, F., 1989. Las ramblas del sur del País Valenciano, IVEI (unpublished).

Sharon, D., 1972. The spottiness of rainfall in a desert area. J. Hydrol. 17, 161-175.

Sharon, D., 1981. The distribution in space of local rainfall in the Namib desert. J. Climatol. 1, 69-75.

Shentsis, I., Meirovich, L., Ben-Zvi, A., Rosenthal, E., 1999. Assesment of transmission losses and groundwater recharge from runoff events in a wadi under shortage of data on lateral inflow, Negev, Israel. Hydrol. Processes 13, 1649-1663.

Sorriso-Valvo, M., Tryan, R.B., Yair, A., Iovino, F., Antronico, L., 1995. Impact of afforestation on hydrological response and sediment production in a small Calabrian catchment. Catena 25, 89-104.

Thornes, J.B., 1976. Semi-arid Erosional Systems. School of Economics and Political Sciences, London.

US Soil Conservation Service, 1957. National Engineering Handbook sec 4, sup. A, Hydrology. Department of Agriculture, Washington, D.C.

Valdés, J.B., Rodríguez Iturbe, I., Gupta, V.K., 1985. Approximations of temporal rainfall from multidimensional model. Water Resour. Res. 21 (8), 1259-1270.

Viessman, J.R., Lewis, G., Knapp, J., 1989. Introduction to Hydrology. Haper \& Row Publishers, New York.

Wallace, D.E., Lane, L.J., 1978. Geomorphic features affecting transmission losses potential on semiarid watersheds. Hydrol. Water Resour. Ariz. Southwest 8, 157-164.

Waymire, E., Gupta, V.K., 1981. The mathematical structure of rainfall representations: 1. A review of the stochastic rainfall models. Water. Resour. Res. 17 (5), 1261-1272.

Woolhiser, D.A., Goodrich, D.G., 1988. Effect of storm rainfall intensity patterns on surface runoff. J. Hydrol. $102,335-354$.

Yair, A., Lavee, H., 1985. Runoff generation in arid and semi-arid zones. In: Anderson, Burt (Eds.), Hydrological Forecasting. John Wiley \& Sons, New York, pp. 183-220. 